Editorial

\title{
Exhausted Women, Exhausted Welfare and the Role of Religion
}

\author{
Martha Middlemiss Lé Mon \\ Uppsala Religion and Society Research Centre, Uppsala University, 75120 Uppsala, Sweden; \\ E-Mail: martha.middlemiss@teol.uu.se
}

Submitted: 14 June 2019 | Published: 24 June 2019

\begin{abstract}
This themed collection is bound together by some foundational observations which have been well documented in earlier research. European post-war welfare systems face challenges related to aging populations, globalization, migration, changing patterns of family and gender roles. The post-war model of welfare dependent on the idea of stable heterosexual families, with male breadwinners and women carers is giving way to more individualized and mobile systems. The four articles and commentary in this issue provide glimpses of the issues within this field that unite contexts as diverse as the Nordic countries, Brazil and the United States. They explore the intersection of welfare, religion and gender charting gendered problems in welfare provision in relation to religious organisation, affiliation and identity. This issue provides examples of how the exhaustion of women and welfare systems is interconnected and the understanding of this crucial to any attempts to reform welfare systems to enhance social inclusion or reduce exclusion.
\end{abstract}

\section{Keywords}

faith-based organisations; gender; religion; religious organisations; welfare; welfare systems

\section{Issue}

This editorial is part of the issue "Exhausted Women-Exhausted Welfare: Understanding Religion, Gender and Welfare in Social Inclusion", edited by Martha Middlemiss Lé Mon (Uppsala University, Sweden).

(C) 2019 by the author; licensee Cogitatio (Lisbon, Portugal). This article is licensed under a Creative Commons Attribution 4.0 International License (CC BY).

The idea for this thematic issue began with a conference held in Uppsala, Sweden, in November 2017 with the title 'Exhausted Women-Exhausted Welfare: Religion and minorities in the transformations of gender and welfare'. This conference was Nordic in scope and arranged by The International Society for the Research and Study of Diaconia and Christian Social Practice (ReDi) and the Uppsala Religion and Society Research Centre (CRS) at Uppsala University. ReDi is an international organisation for those interested in studies and research on the contributions made by churches to social and health care and CRS is a multi-disciplinary research centre which has hosted and managed a number of larger international projects focusing on the role of religion and religious organisations in welfare particularly, but not exclusively, in Europe and with a particular focus also on gender issues in this field. This background is important as it explains the somewhat Nordic starting point for the call for contributions to this volume and also the focus on religion and religious organisations. 'Exhausted Women-
Exhausted Welfare' would otherwise be an equally good title for a themed edition which did not focus on religion specifically.

This themed collection is bound together by some foundational observations which have been well documented in earlier research. European post-war welfare systems face challenges related to aging populations, globalization, migration, changing patterns of family and gender roles. The post-war model of welfare dependent on the idea of stable heterosexual families, with male breadwinners and women carers is giving way to more individualized and mobile systems. New care chains have developed, with migrants and guest workers filling the gaps in strained safety nets and civil society organisations increasingly (re)shouldering roles as welfare providers. The welfare system appears increasingly exhausted and symptoms of exhaustion hit women in particular. These developments raise questions as to the implications of social inclusion (or exclusion) for individuals from a variety of backgrounds in welfare. This thematic issue there- 
fore sought contributions which addressed gendered transformations of the welfare system and the implications of this for social inclusion with a particular focus on the Nordic countries and the role of organised religion. The hope was that this issue could contribute to highlighting inequalities in welfare and models of good practice through presenting explorations of the exhaustion of welfare systems and the women bearing the brunt of this. The Nordic focus being of particular interest as Nordic welfare states have been seen as beacons of both comprehensive state welfare provision and gender equality with social inclusion as a key element. Strains are showing, but the fact that they are still seen to be relatively well-functioning and gender equal, means that the Nordic model's failures and successes of social inclusion are still of interest as examples of good practice.

Within the Nordic model the system of church welfare provision is of specific interest. Churches, traditionally important welfare actors, were marginalised during the twentieth century and religion began to be seen as a private matter for individuals. The Nordic countries today are seen as highly secularised and yet significant numbers still belong to the majority churches, while churches and faith-based organisations have, in recent years, been lauded as important actors in welfare. With regard to gender their role is, however, ambiguous and questions of the roles women have been given within religious organisations, as well as the gender values that these organisations have propagated, are important to understanding ongoing developments. Studies of religious institutions in welfare, can therefore provide a timely and important nuance to discussion as to how transforming welfare societies can continue to enhance social inclusion and reduce exclusion.

Ideström and Linde (2019) in their contribution "Welfare State Supporter and Civil Society Activist: Church of Sweden in the 'Refugee Crisis' 2015" most clearly address the particular role which the majority Church in Sweden can and does play in relation to welfare and social inclusion at a local level. This article, based on study of a parish church and its work with refugees conducted using participatory research highlights both models of good practice and examples of how Churches in Nordic countries can and do interact with social authorities. It also highlights the challenges and is in this respect an important contribution to a discussion of how religious organisations in the welfare sphere can or can't focus on their core mission and collaborate with other organisations and authorities, as well as also providing important examples of how general strains on the welfare system manifest themselves in social inclusion or exclusion at the local level.

Beecheno's (2019) contribution also lifts this issue of competing logics for faith-based welfare providers in her study of "Faith-Based Organisations as Welfare Providers in Brazil: The Conflict over Gender in Cases of Domestic Violence". Her article based on ethnographic research in Brazil shows the constant negotiations that are ongoing between organisations providing welfare and the state or legal system, but also between care-givers and providers as well as the internalisation of these tensions by individuals. She shows in her work how the women both giving and receiving care in the organisations she has studied are stuck in value conflicts, not always their own, which set the parameters for the support they receive and the likelihood of such support enhancing social inclusion in Brazilian society.

Garlington, Durham, Bossaller, Shadik and Shaw (2019) shift the focus to the United States, a context also highlighted in the commentary provided by Sullivan (2019). These two texts can thus helpfully be read in connection. Garlington et al.'s (2019) article "Making Structural Change with Relational Power: A Gender Analysis of Faith-Based Community Organizing" focuses on community organising in the form of 'justice ministry' and the roles that women take on within this. This text therefore focuses less on religious organisations as service providers, but rather on local organisations which seek to empower their own members to make a difference for themselves and their own local communities. The authors conduct a gender analysis of an interview study which focused on five different local contexts and analyse how expectations and work are constrained or facilitated by both cultural expectations of gender roles and power dynamics.

If Ideström and Linde's (2019) contribution most clearly addressed the role of the Church in the Nordic welfare system, Bradby, Phillimore, Padilla and Brand's (2019) article in bringing focus back to the European (and to some extent Nordic) context is the article which most directly addresses issues of Welfare work as a gendered enterprise, with women taking on a range of responsibilities for themselves and others which often remains invisible. The article is based on a multi-method comparative European study that looked at access to healthcare in diverse neighbourhoods in Germany, UK, Sweden and Portugal. Using the concept of 'healthcare bricolage' as a tool for analysis the authors show how complex variations of women's bricolage in relation to public healthcare show how gendered caring roles intersect with migration, status and social class. Their article is thus an important contribution to a broader discussion of how the exhaustion of women and welfare systems is interconnected and the understanding of this crucial to any attempts to reform welfare systems to enhance social inclusion or reduce exclusion.

As this brief introduction shows, in the end the contributions submitted to and accepted for the volume expanded the geographical scope significantly. The four articles and commentary thus provide glimpses of the issues that unite contexts as diverse as the Nordic countries, Brazil and the United States and while being informative reading in their own right individually, together also show that further collections of this nature are needed. Works that explore the intersection of welfare, religion and gender and charting gendered problems 
in welfare provision can illuminate the double burdens borne by many women and bring a hitherto neglected element to discussions of the future of welfare societies, in the search for a vision and praxis for an inclusive society.

\section{Acknowledgments}

The editor would like to thank particularly Ninna Edgardh and Hannah Bradby who provided helpful advice and support in the conception of this themed number. The publication of this issue was made possible by funding from the research programme The Impact of Religion: Challenges for Society, Law and Democracy at Uppsala University.

\section{Conflict of Interests}

The author declares no conflict of interests.

\section{References}

Beecheno, K. (2019). Faith-based organisations as welfare providers in Brazil: The conflict over gender in cases of domestic violence. Social Inclusion, 7(2), 14-23.

Bradby, H., Phillimore, J., Padilla, B., \& Brand, T. (2019). Making Gendered Healthcare Work Visible: OverLooked Labour in Four Diverse European Settings. Social Inclusion, 7(2), 33-34.

Garlington, S. B., Durham Bossaller, M. R., Shadik, J. A., \& Shaw, K. A. (2019). Making structural change with relational power: A gender analysis of faith-based community organizing. Social Inclusion, 7(2), 24-32.

Ideström, J., \& Linde, S. (2019). Welfare state supporter and civil society activist: Church of Sweden in the "refugee crisis" 2015. Social Inclusion, 7(2), 4-13.

Sullivan, S. C. (2019). Religion, gender, and social welfare: Considerations regarding inclusion. Social Inclusion, $7(2), 44-47$.

\section{About the Author}

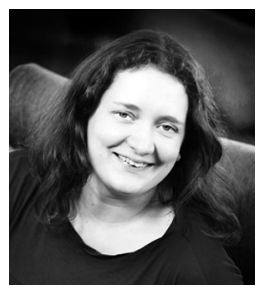

Martha Middlemiss Lé Mon is a Sociologist of religion with a specialism in issues of welfare, religion and values. She has published on the role of Churches in welfare provision in Europe and in Africa and on questions of values and gender in relation to welfare issues in Sweden and UK. She is currently director of the Uppsala Religion and Society Research Centre at Uppsala University, Sweden and a member of the scientific board of the research programme The Impact of Religion: Challenges for Society, Law and Democracy. 